\title{
PENINGKATAN NILAI GUNA PEPAYA MENJADI SAOS PEPAYA DI PERUMAHAN PATAM INDAH PATAM LESTARI SEKUPANG
}

\author{
Hazimah $^{* 1}$, Welly Sugianto ${ }^{2}$, Nurlinda Ayu Triwuri ${ }^{3}$ \\ ${ }^{1,2}$ Program Studi Teknik Indusrti Fakultas Teknik dan Komputer, Universitas Putera Batam, Jl. \\ R. Soeprapto, Muka Kuning, Batam,Indonesia \\ ${ }^{3}$ Politeknik Negeri Cilacap, Jl. Dr.Soetomo No.1 Sidakaya, Cilacap, 53212, Indonesia \\ e-mail: ${ }^{* 1}$ hazimahima1987@gmail.com, ${ }^{2}$ sugianto.welly@gmail.com, \\ ${ }^{3}$ nurlindaayutriwuri@gmai.com
}

\begin{abstract}
Informasi Artikel
Revisi Akhir: -

Kata Kunci

Saos, Pepaya, asam folat

Korespondensi

No. HP: 082387143394
\end{abstract}

Diterima Redaksi: 29 April 2019

Diterbitkan Online: 6 Mei 2019

\section{PENDAHULUAN}

Saat ini telah penyedap makanan banyak ditambahkan didalam masakan oleh berbagai kalangan masyarakat. Cita rasa, bau, komposisi, serta warna saos yang unik dan menarik memicu masyarakat menjadikannya sebagai menu sehari-hari. Makanan di restoran cepat saji tidak berasa cita rasa tanpa adanya saos seperti ayam goreng, burger, spageti atau pizza.

\section{Abstract} dipasarkan.
Saos digunakan sebagai penyedap bahan makanan. Saos dibuat dari berbagai buah-buahan, salah satu buah-buahan dapat digunakan sebagai bahan dasar untuk membuat saos adalah buah pepaya karena terdapat kandungan gizi yang baik bagi tubuh seperti karbohidrat, serat, asam folat, vitamin, dan berbagai macam mineral yang dibutuhkan oleh tubuh. Saos adalah bubur buah kental berwarna menarik (biasanya merah), mempunyai aroma dan rasa yang merangsang (dengan tanpa rasa pedas). Walau kandungan air dalam saos cukup besar, masa simpan saos dalam jangka waktu yang panjang karena asam, gula, dan garam sebagai pengawet alami. Saos juga dapat diolah dari bahan lainnya seperti cabai, dan tomat. Setiap bahan yang digunakan pada pembuatan saos mempunyai fungsi tertentu yang betujuan untuk memperbaiki rasa, warna, aroma, dan kekentalan. Gula akan memberikan rasa manis, garam akan memberikan rasa asin, cuka akan memberikan rasa asam dan sekaligus memberikan efek pengawetan karena sebagian besar mikroorganisme tidak tahan terhadap kondisi asam. Rempah-rempah akan memperbaiki aroma dan cita rasa. Pembuatan saos pepaya melalui beberapa tahap yaitu pembuatan pasta, pencampuran bahan tambahan makanan, pemasakan dan pengemasan. Dalam pembuatan pasta pepaya, pepaya segar dihaluskan terlebih dahulu, kemudian ditambahkan bahan yang lainnya dan setelah produk saos sudah jadi dilanjutkan proses pengemasan selanjutnya saos sudah siap untuk

Makan mie bakso, tahu dan siomay di warung-warung, juga akan terasa kurang nikmattanpa kehadiran saos. Saos diartikan bahwa produk bahan pangan umpamanya sayuran, tomat dan papaya yang telah dihancurkan (berbentuk bubur).

Pepaya terdapat gizi pangan yang baik untuk tubuh seperti kandungan karbohidrat $(9,81 \mathrm{~g})$, serta $1,80 \mathrm{~g}$ atau $4,5 \%$ dari jumlah harian yang dibutuhkan oleh tubuh. Pepaya mengandung beberapa vitamin B-kompleks 
dalam jumlah yang baik, seperti folat, Niasin, Asam Pantotenic, Piridoksin, Riboflavin, serta Tiamin. Vitamin penting lain yang bisa diperoleh dari pepaya adalah Vitamin A, Vitamin C, Vitamin E, dan Vitamin K. Pepaya juga memiliki muatan dengan jumlah yang cukup baik, yaitu kalium serta beberapa mineral penting seperti kalsium (K), zat besi $(\mathrm{Fe})$, magnesium $(\mathrm{Mg})$, pospor $(\mathrm{P})$, dan zinc $(\mathrm{Zn})$. Fitonutrisi penting yang ditemukan dalam pepaya yaitu betakaroten (276 mikrogram), Beta Crypto-xanthin (761 mikrogram) dan Lutein-zeaxanthin (75 mikrogram).

Dalam pengabdian ini, saos yang akan digunakan yaitu dari bahan buah pepaya. Saos pepaya adalah serupa penyedap masakan, berbentuk padat, berwarna cerah, yang terbuat dari buah pepayasegar yang telah ranum. Bumbu-bumbu dan campuran daging buah papaya sebagai dasar pembuatan saos. Warna buah (kuning atau merah) sebagai campuran akan memberikan pola warna yang berbeda pada bubur kental. Pepaya digunakan sebagai bahan dasar dengan tujuan untuk mengurangi biaya produksi dari saos tersebut sehingga diharapkan saos yang dihasilkan nantinya dapat terjangkau oleh masyarakat.

Terbatasnya ilmu pengetahuan tentang pengolahan buah pepaya menjadi produk olahan serta minimnya pengetahuan ibu-ibu tentang akibat-akibat yang ditimbulkan bagi kesehatan oleh produk olahan saus yang ada di pasaran, sehingga kami merasa perlu untuk menginformasikan hal ini kepada masyarakat.

Untuk mendukung program pemerintah di bidang pembangunan daerah berdasarkan daya saing melalui terobosan dan keterampilan, maka perlu adanya penerapan teknologi tepat guna untuk membuat suatu produk inovatif yang berdaya saing dipasaran. Dalam hal ini pusat pengabdian pada masyarakat Universitas Putera Batam mencoba memperkenalkan pembuatan saus pepaya yang mudah, tahan disimpan lama dan dapat dimanfaatkan buat keperluan seharihari agar dapat meningkatkan nilai tambah pengolahan masyarakat melalui peningkatan ketrampilan dalam mengolah buah pepaya.

\section{METODE}

\subsection{Peralatan dan Bahan}

Adapun peralatan yang berkaitan dengan kegiatan pembuatan saos dari pepaya yakni peralatan yang berkaitan dengan peralatan dapur yakni panci, tungku atau kompor, sendok pengaduk, kain saring dan blender. Sedangkan bahan-bahan yang digunakan yaitu buah pepaya ranum $1 \mathrm{~kg}$, gula pasir $1 / 2$ $\mathrm{kg}$, bawang merah (bersih) $1 / 4 \mathrm{~kg}$, bawang putih (bersih) 300 gr, asam cuka 25\% $250 \mathrm{ml}$, asam sitrat Kristal (pati jeruk) 50 gram, cabai merah 
(tanpa biji) 500 gram, dan garam dapur 250 gram

\subsection{Cara membuat saos pepaya}

Adapun cara peambuatan saos dari biah pepaya adalah

1. Bersikan buah papaya, kupas dan buang bijinya, selanjutnya dipotong-potong lalu blender dengan sampai menjadi bubur, lalu dimasukkan dalam panci;

2. gula dan garam ditambahkan secukupnya, aduk hingga matang;

3. ambil sari pati bawang merah, bawang putih, cabai, menngunakan kain kacu/penyaring. masukkan saripati di dalamn pasta papaya.

4. Didihkan kurang lebih 30 menit. Kemudian cuka dan asam sitrat kristal ditambahkan ke dalam saos, aduk hingga rata;

5. Masukkan saos panas-panas ke dalam botol hingga permukaan sekitar 1 sampai $1 \frac{1}{2} \mathrm{~cm}$ di bawah permukaan mulut botol. Segera tutup hingga rapat.

6. Masukkan botol yang berisi saos ke dalam air mendidih selama 30 menit. Angkat dan biarkan terbalik selama 5 menit.

\section{HASIL DAN PEMBAHASAN}

\section{$3.1 \quad$ Hasil}

Pengabdian dilaksanakan di perumahan Kav. Patam Indah Blok C
No.115 RW. 01/RT.07 Kelurahan Patam Lestari, Kecamatan Sekupang. Mata pencaharian utama masyarakat Kelurahan Patam Lestari adalah pedagang dan pegawai swasta atau pemerintah. Pembinaan ini berfokus hanya pada Alresqi Wahyuni yang ada di perumahan Kav. Patam Indah Blok C No.115, ayahnya bekerja serabutan yakni pernah membuat usaha ternak ikan lele tetapi tidak berjalan dengan lancar dan sekarang tahun 2016 membuka usaha ternak jangkrik, sedang ibundanya hanya bekerja sebagai ibu rumah tangga serta Alresqi Wahyuni sudah berhenti bekerja tetapi punya niat untuk buka usaha akan tetapi masih bingung usaha apa yang harus dijalankan. Salah satu tujuan dari pengabdian masyarakat yang dilakukan yaitu untuk berbagi pengetahuan dan wawasan tentang pembuatan saos dari bahan dasar pepaya. Berdasarkan tujuan tersebut, cara yang dapat dilakukan yaitu memberikan pembinaan pembuatan saos dan produk saos tersebut dapat dipasarkan oleh Alresqi Wahyuni.

Pengabdian dilaksanakan selama 4 (empat) hari, pengabdian ini dilakukan pada hari minggu tanggal 17, 24, 31 Januari 2016, dan minggu tanggal 7 Februari 2016 yang bertempat di rumah 
Alresqi Wahyuni berjalan dengan lancar dan kondusif. Peserta yang hadir sebanyak 2orang yang terdiri dari Alresqi Wahyuni dan Cut Rizki Marisa Selvia. Perumahan ini masih banyak rumah yang hanya dibangun seadanya karena diperumahan ini merupakan tanah kavling sehingga jika tidak langsung dibuat bangunan maka tanah yang sudah dibeli dianggap tidak ada pemiliknya. Peserta yang mengikuti pembinaan antusias dengan materi dan praktek pembuatan saos yang disampaikan. Tim dosen yang melaksanakan pengabdian terdiri atas 3 orang dosen. Pada laporan pengabdian ini, pengabdi melakukan pembinaan pembuatan saos dari buah pepaya kepada 2 (dua) orang saja dan berharap kedua peserta ini dapat menjadikan produk saos sebagai usaha. Kegiatan pembinaan ini dimaksudkan untuk memberikan tambahan wawasan dan ilmu pengetahuan kepada kepada Alresqi Wahyuni dan Cut Rizki Marisa Selvia sekaligus membimbing mereka dalam membuka usaha.

Buah pepaya sangat mudah dijumpai di kota Batam yakni di pasar-pasar. Buah pepaya banyak mengandung gizi terutama karbohidrat dan serat sehingga mampu membantu proses pencernaan. Saos pepaya adalah saosberbahan dasar pepaya, pembuatan saos pepaya sama halnya dengan pembuatan saos tomat bahkan jauh lebih mudah untuk proses pemasakan saos karena pepaya mengandung lebih sedikit kadar air dan relative singkat atau cepat. Pembinaan ini dilakukan agar produk saos yang dibuat terbuat dari bahan yang berkualitas dan berasal dari bahan alami.Berbagai tantangan dan rintangan tak luput dari kegiatan yang dilakukan oleh tim pengabdi. Tantangan terberatpada saat kegiatan pembinaan dilaksanakan mencari perpaduan bahan dasar untuk memperoleh rasa saos yang enak dan mencari cara agar hasil produksi saos lebih banyak. Hambatan yang dihadapi oleh tim pengabdi adalah kurangnya waktu untuk melakukan eksprimen agar saos yang dihasilkan lebih enak dan bahan-bahan isi soas yang lebih bagus digunakan agar hasil saosnya lebih banyak

\subsection{Pembahasan}

Dari hasil pengabdian yang telah dilaksanakan oleh tim dosen pengabdi Universitas Putera Batam, terlihat bahwa terdapat beberapa kelemahanyang menjadi kekurangan dalam pengabdian ini. Kelemahan tersebut akan dapat diatasi dengan 
kerjasama yang baik antar tim pengabdi dan peserta pengabdi. Pengabdi menganalisa bahwa untuk mendapat rasos saos yang enak dan pas dilidah maka harus sering melakukan uji coba dengan berbagai perbedaan kadar bahan yang digunakan dan untuk menambah volume hasil produksi saos maka harus ditambahkan bahan pengisi saos seperti dengan menambahkan sedikit tepung maizena. Pengabdian ini dimaksudkan untuk menambah wawasan dan ilmu pengetahuan mengenai alat dan bahan serta cara dalam pembuatan saos berbahan dasar pepaya serta sebagai bahan pertimbangan sebagai produk usaha yang ingin dilaksanakan oleh Alrezqi Wahyuni.

Produk saos ini juga ditekankan mengutamakan bahan dasar yang segar dan selalu menjaga kualitas saos yang dihasilkan agar nantinya mampu bersaing dipasaran dengan memiliki dasar untuk tetap mengutamakan menjaga kesehatan orang banyak dari produk yang dijual. Sebagaimana yang telah disebutkan diatas, tim pengabdi dan peserta telah melakukan beberapa kali melakukan pengulangan uji coba pembuatan saos agar hasilnya enak dan banyak namun tim pengabdi terkendala oleh waktu untuk melakukan pengembangan lebih lanjut pembuatan saos pepaya. pembinaan ini setidaknya memberikan informasi bahwa membuat saos tidak hanya memanfaatkan tomat yang harga mahal dan pembuatannya membutuhkan proses yang lebih lama karena tomat mengandung kadar air yang lebih tinggi dibandingkan pepaya, setelah proses pembuatan, saos bisa langsung digunakan serta saos yang dibuat sendiri terjamin kehigienisannya, saos yang dibuat sendiri juga tidak butuh pengawet supaya tahan lama. Evaluasi dilakukan untuk mengetahui hasil-hasil yang dicapai selama kegiatan ini dilaksanakan dengan cara melakukan pengamatan selama kegiatan berlangsung dan survey lapangan. Dari evaluasi yang dilakukan diperoleh gambaran bahwa selama pembinaan berlangsung peserta tampak antusia, penuh perhatian dan suasana kegiatan menunjukkan interaksi yang baik.

Menurut pendapat peserta kegiatan pembinaan ini sangat membantu mereka dalam membuat suatu pertimbangan dalam membuka usaha yang menghasilkan produk yang sehat dan tetap memperhatikan kesehatan orang banyak bukan hanya memikirkan keuntungan yang ingin dicapai. Dari hasil uji coba tester yang dilakukan oleh peserta kepada masyarakat sekitar 
bahwa saos yang dihasilkan haruslah konsisten rasa dan harga yang akan dijual kepasaran nantinya. Dari hasil informasi yang didapatkan bahwa peserta sudah melakukan beberapa kali pembuatan soas dan dijual kepada masyarakat sekitar. Dari uraisan diatas, tim pelaksana mendapatkan gambaran bahwa kegiatan pembianaan ini dikategorikan sukses dengan hasil yang cukup memuaskan, karena peserta memperoleh pengetahuan tentang pembuatan saos pepaya dan dampakdampak yang ditimbulkan oleh pemakaian saos instan yang berlebihan. Peserta juga mempunyai gagasan untuk mengembangkan usaha utnuk membuat saos pepaya untuk dijadikan sebagai income bagi mereka.

Untuk itu, pengabdi menilai bahwa untuk kegiatan pengabdian di masa yang akan datang akan lebih baik jika pengabdi dan pihak terkait lokasi pengabdian untuk menjalin komunikasi yang lebih persuasif dan intens, dan jangka waktu yang lebih lama sehingga saos yang dihasilkan bisa langsung dipasarkan.

\section{KESIMPULAN}

Upaya untuk meningkatkan nilai ekonomis pepayaadalah memanfaatkan pepaya sebagai bahan dasar dalam pembuatan saosyang memiliki nilai jual. Pembuatan saos dari pepaya ini sangatlah sederhana, melalui binaan ini diharapkan kegiatan pembuatan saos dari pepaya akan menjadi kebiasaan yang dapat menghasilkan tambahan pendapatan.

Saus pepaya adalah pemanfaatan dari buah pepaya yang dibuat berupa pasta dan dicampur dengan bumbubumbu.Teknik pembuatan saos pepaya yang telah dilakukan diperumahan Kav.Patam Indah Blok C No.115 RW. 01/RT.07 Kelurahan Patam Lestari, Kecamatan Sekupang yakni melakukan proses persiapan bumbu saos, proses penghalusan bahan-bahan saos, dan proses pemanasan/pengolahan.

Dari kegiatan pengabdian yang dilakukan oleh tim pengabdi bahwa diharapkan peserta mampu mengembangkan produk saos pepaya ini menjadi produk yang bisa dipasarkan.

\section{SARAN}

Berdasarkan pengamatan dari kegiatan pengabdian di Kav. Patam Indah Blok C No.115 RW. 01/RT.07 Kelurahan Patam Lestari, Kecamatan Sekupang bahwa perlu membuat produk saos pepaya yang lebih enak sebagai salah satu produk yang mampu lebih 
higienes. Dengan demikian maka selain saos dibuat untuk dimakan dan dapat juga dimanfaatkan untuk meningkatkan taraf perekonomian.

\section{UCAPAN TERIMA KASIH}

Ucapan terima kasih kepada Universitas Putera Batam melalui LPPM yang telah memberi dukungan financial terhadap pengabdian ini.

\section{DAFTAR PUSTAKA}

[1] Abdullah, R., Rasmiwetti, Anwar, L dan Miharty. 2012. Pembuatan Saus Tomat di PKK Dusun Sawah Desa Sawah Kecamatan Kampar Utara Kabupaten Kampar. Universitas Riau.

[2] Aryani, R. D.P. 2006. Pengaruh Lama Pemasakan terhadap Karakteristik Fisik, Kimia, dan Organoleptik Saus Pepaya (Carica papaya, L).Skripsi. Universitas Jember.

[3] LPPM.2015. Panduan Pengabdian kepada Masyarakat Universitas Putera Batam.LPPM UPB Batam. 